\title{
Efficacy of Bio - Agents and Lantana camara against Damping - Off (Pythium aphanidermatum) of Chilli (Capsicum annuum L.)
}

\author{
Gandham Grace Susanthi* and Sunil Zacharia
}

\author{
Department of Plant Pathology, Sam Higginbottom University of Agriculture Technology and \\ Sciences, Allahabad - 211007, India \\ *Corresponding author
}

\section{Keywords}

Damping-off, Chilli, Pythium aphanidermatum, Trichoderma harzianum, Pseudomonas fluorescens, Lantana camara

Article Info

\section{Accepted:}

20 May 2021 Available Online: 10 June 2021
In chilli (Capsicum annиum L.) several diseases are caused from fungal, bacterial and viral origin. Among the fungal diseases, damping off caused by species of Pythium is very common in the nursery which causes about 90 per cent mortality in nurseries and fields. Present experiment was carried out in in-vitro and in-situ conditions at Department of Plant Pathology, SHUATS in Completely Randomized Design with eight treatments and three replications each. The dominant pathogen, which causes damping-off of chilli, was isolated and identified as Pythium aphanidermatum. Biocontrol agents Trichoderma harzianum and Pseudomonas fluorescens were isolated from different crops of healthy rhizosphere soils in different geographical regions. The in-vitro studies revealed that Lanatana camara $(20 \mathrm{ml})$ carbendazim fungicide $(8 \mathrm{ppm})$ showed the highest mycelial growth inhibition (100\%) over the control and both antagonists were compatible with each other. Under nursery conditions, maximum germination percentage was recorded in carbendazim seed treatment (80 \%), Lantana camara $(100 \mathrm{ml} / \mathrm{kg})$ soil treatment $(76.00 \%)$, [Trichoderma harzianum+ Pseudomonas fluorescens] +Lantana camara [seed] + soil treatment (70.66\%), Trichoderma harzianum + Pseudomonas fluorescens seed treatment (68.00\%), Trichoderma harzianum seed treatment $(64.00 \%)$, Pseudomonas fluorescens seed treatment $(60.00 \%)$ when compared to the $\mathrm{T}_{0}$ - relative control (treated control) $(13.33 \%)$ and $\mathrm{T}_{1}$ - absolute control (untreated control) (78.66 \%).Maximum root length was recorded in treatment carbendazim $(4.29 \mathrm{~cm})$ followed by $\mathrm{T}_{5}-$ Trichoderma harzianum + Pseudomonas fluorescens $(3.80 \mathrm{~cm})$. Maximum shoot length was recorded in treatment $\mathrm{T}_{7}-$ carbendazim $(4.52 \mathrm{~cm})$ followed by $\mathrm{T}_{5}-$ Trichoderma harzianum + Pseudomonas fluorescens $(4.1 \mathrm{~cm})$.

\section{Introduction}

Among the fungal diseases, damping off caused by Pythium species is essentially soil borne disease fungi, which causes seedling rot and damping off in many crops including a chilli and tomato. In nursery plot, disease show infection in patches and within two to 
four days the entire lot of seedling may be destroyed (Ghutukade et al., 2013). Dampingoff incited by Pythium aphanidermatum (Edson) Fitz. caused more than 60\% mortality of seedlings in both nurseries and field grown crops (Muthukumar et al., 2010). Pythium aphanidermatum, a member of class oomycetes, is an unspecialized parasite that has a wide host range. It affects the plant both in pre and post emergence stage in nursery beds (Jeyaseelan et al., 2012).

Biological control agents colonize rhizosphere and provide protection against various soil borne plant pathogens (Kloepper et al., 1989). Fungi in the genus Trichoderma are of increasing interest as bioprotectants.

Another important group of biocontrol agents are rhizobacteria. Among them Pseudomonas florescens is capable of suppressing wide range of plant pathogens (Raghunandan et al., 2013). Utilization of plant extracts which are natural source of antimicrobial substances, considered as safe and degraded by natural microorganism.

\section{Materials and Methods}

\section{Isolation of the pathogen}

Isolation of Pythium species was carried out from infested nursery soil by using French bean/bottle guard as bait. Fruits were treated with carbendazim $(500 \mathrm{ppm})+$ streptocycline (10 0ppm) solution for 24 hours and then it was transferred to infested soil.

The entire french bean / bottle guard fruits were covered with white fluffy mycelial growth within 24 hours and it was aseptically transferred to potato dextrose agar plates.

Thus, the pathogen was isolated within five days without any other fungal and bacterial contamination (Patel et al., 2014).

\section{Identification of the pathogen}

Identification of Pythium aphanidermatum was based on standard keys suggested by (Plaats-Niterink, and Van der, A. J. 1981; Butler, 1907 and Dick, 1990). Slides were prepared from the culture and stained with cotton blue according to Parija and Prabhakar, (1995) and examined under the light microscope.

\section{Mass multiplication of Pythium aphanidermatum}

The mass culture of Pythium aphanidermatum was prepared on sorghum grain medium using the method of Khan et al., (2004). Sorghum grain and water were mixed in ratio of 1:1.25 $(\mathrm{w} / \mathrm{v})$ and boiled up to two whistles in pressure cooker.

Then 200 gm of such mixture was filled in $500 \mathrm{ml}$ Erlenmeyer flasks. The sorghum grains were sterilized in an autoclave at $15 \mathrm{lbs}$ for 20 minutes. After that, the flasks were inoculated with $5 \mathrm{~mm}$ mycelial discs of Pythium aphanidermatum and incubated for 7 days at $28 \pm 1^{\circ} \mathrm{C}$. The grains turn whitish due to mycelial growth of the test fungus. For soil application in nursery experiment, the grains colonized by Pythium aphanidermatum was mixed in soil as such @ $10 \mathrm{~g} / \mathrm{kg}$ sterilized soil.

\section{Isolation of Trichoderma harzianum and Pseudomonas fluorescens}

Trichoderma harzianum was isolated by serial dilution technique using TSM agar plate. The obtained strains were purified on TSM agar plates using sub-culture technique.

Pseudomonas fluorescens was isolated by serial dilution method using King's B agar. The fluorescent strains were purified on King's B agar plates using single spore technique. 


\section{Purification and identification of Trichoderma sp. \\ Trichoderma sp. was purified by single spore culture (Tuite, 1969b). Identification and maintenance of Trichoderma sp. was based on colony characters (Gams and Bisset, 1998).}

\section{Purification and Identification of Pseudomonas fluorescens}

The green fluorescent colonies under UV light were picked up, purified by repeated streaking on the same medium and checked for their fluorescens (Sandheep et al., 2013). For the identification of efficient antagonist rhizobacteria biochemical and functional tests were done and identified according to Bergey's manual of systematic bacteriology.

\section{In-vitro evaluation of fungicide, botanical and bio-agents}

\section{Poison Food Technique}

The extract was prepared from Lantana camara leaves which were antifungal in nature. Fresh leaves were grinded with the help of pestle and mortar by taking $(1: 1 \mathrm{w} / \mathrm{v})$ one gram of extract was added in $1 \mathrm{ml}$ distilled water and filtered through muslin cloth and $100 \%$ plant extract solution was prepared. The extracts were poured in the flasks plugged with cotton and heated at $100^{\circ} \mathrm{C}$ for 10 minutes to avoid contamination.

Appropriate concentration (20\%) of plant extract was incorporated to potato dextrose medium agar for inoculation of the test pathogen in sterilized petridishes. The isolated pathogen was grown on potato dextrose agar medium was placed at the center of petridishes containing defined concentration of the poisoned medium and incubated at $27 \pm 2^{\circ} \mathrm{C}$ for 6 days. Radial growth $(\mathrm{cm})$ of fungus was measured after inoculation till 6 days at an interval of $24 \mathrm{hrs}$. per cent growth inhibition of the test pathogen over control was worked out (Vincent, 1927) as follows,

$$
I=\frac{\mathrm{C}-\mathrm{T}}{\mathrm{C}} \times 100
$$

Where, $\mathrm{C}=$ Radial growth in control, $\mathrm{T}=$ Radial growth in treatment.

\section{Dual culture Technique}

The antagonistic activity of Trichoderma sp. and Pseudomonas fluorescens against Pythium aphanidermatum was studied in dual culture method (Falck, 1907). So the antagonist was evaluated by dual culture technique. The pathogen was inoculated on one side of the petri plate filled with $20 \mathrm{ml}$ of PDA and antagonist was inoculated at exactly opposite side of the same plate by leaving 3-4 cm gap.

For this, actively growing five days old culture was used. In case of bacterial antagonist evaluation, bacterial antagonist was streaked in the plates and fungal discs were placed at one corner of the plates. After a period of incubation, when the growth of the pathogen was measured at 48, 72, 96 and $120 \mathrm{hrs}$. Percent inhibition over check was worked out according to the equation given by (Vincent, 1927).

PIRG=R1-R2/R1 X 100

Where, R1 = Radius of Pythium aphanidermatum colony in dual control plate;

R2 = Radius of Pythium aphanidermatum colony in dual culture plate

Testing of compatibility between fungal and bacterial bio-control agents

The method described by Nikam et al., (2007) was used for in - vitro testing. Bacterial antagonist was streaked with the help of sterilized inoculating needle at one end of the 
PDA Petri plate at a distance of $5 \mathrm{~mm}$ from the periphery of petriplate. The bacterial isolate was allowed to grow for $24 \mathrm{hr}$ at $26 \pm 2$ C. A $5 \mathrm{~mm}$ diameter plug from a 5- dayold culture of Trichoderma harzianum was placed in the opposite direction of the plate (approximately four $\mathrm{cm}$ apart). After 3 days incubation at $26 \pm 2 \mathrm{C}$ the zone of inhibition, if any, was measured.

In- situ evaluation of fungicide, botanical and bio-agents

The in-situ experiment was conducted in greenhouse which is located in the research plot of the department of Plant Pathology, Sam Higginbotton University of Agriculture, Technology and Sciences, during the Rabi (February) season of 2017-18. Experiment was laid - out in completely randomized design with three replications in green house.

\section{Details of Experiment}

Experimental design : CRD

Number of replications : 3

Number of treatments : 8

Total number of trays : 24

Tray size : $23 \times 15 \mathrm{~cm}$

Season : Rabi

Selected crop : Chilli

Variety : G-4

Seed rate : $1 \mathrm{~kg} / \mathrm{ha}$

\section{Nursery}

The present experiment was conducted to test the efficacy of Trichoderma harzianum,
Pseudomonas fluorescens, Lantana camara alone and combined applications against damping-off of chilli. The normal surface soil was collected randomly from the field and it was thoroughly mixed, sieved through screen. Then the soil was sterilized at 15 pound pressure per inch for $1 \mathrm{hrs}$ consequently for two times with an interval of $24 \mathrm{hrs}$. The well sterilized plastic containers (disinfected with 5 $\%$ solution of copper sulphate) with drainage hole of $1 \mathrm{~cm}$ diameter at the bottom were filled with sterilized amended soil with $1 \mathrm{~kg}$ of each. The sterilized soil was mixed with pathogen inoculum (@10gm kg ${ }^{-1}$ soil prior to one week of sowing).

The soil inoculated with pathogen was covered and not disturbed in order to facilitate the growth of the pathogen. Trays were irrigated regularly. Seed and soil treatments were given and chilli seeds were sown in these trays (@25 seeds per tray). Non-treated seeds sown in the infested soil served as positive control. Non-treated seeds sown in non infested soil served as negative control.

\section{Seed treatment}

Seeds were smeared with bio - agents one day before sowing. Bio-agent culture from 1 Petri plate was used for smearing 48 seeds. Treated seeds were sown in the infested soil in plastic containers. For the combined application of bio-control agents the same was followed (Zagade et al., 2012).

\section{Soil Treatment}

The $20 \%$ aqueous extract of Lantana camara was applied (alone and in combination with biocontrol agents) as soil drenching (100 $\mathrm{ml} / \mathrm{kg}$ soil) (Gholve et al., 2014).

\section{Observations to be recorded}

Germination percentage at 25 DAS 
Damping - off incidence at 15 DAS

Shoot length and root length at 45 DAS

Disease incidence will be calculated by using the following formula

Disease incidence (\%)

$=\frac{x 1}{x 2} \times 100$ Where,

$X_{1}=$ No. of infected plants/leaves

$X_{2}=$ Total no. of plants/leaves

Results and Discussion

In vitro evaluation

Compatibility between Trichoderma harzianum and pseudomonas fluorescens

Absence of inhibition zone between the two biocontrol agents indicated that these were compatible with each other.

Efficacy of selected treatments on the mycelial growth of Pythium aphanidermatum by dual culture technique and poisoned food technique

The two isolates Trichoderma harzianum, Pseudomonas fluorescens and one botanical extract Lantana camara and fungicide carbendazim were screened against Pythium aphanidermatum by dual culture and poison food test for their antagonistic and fungicide ability.

Maximum inhibition growth was recorded in both $\mathrm{T}_{7}$ - treated check (Carbendazim) $(100 \%)$ and $\mathrm{T}_{4}$ - Lantana camara - (100\%), followed by $\mathrm{T}_{5}$ - Trichoderma harzianum + Psuedomonas fluorescens (81.11\%), $\mathrm{T}_{2}$ Trichoderma harzianum (76.66\%), $\mathrm{T}_{3}$ -
Psuedomonas fluorescens (72.22 \%) as compared to the untreated control. At $7^{\text {th }}$ DAI the percent mycelial inhibition of the all the treatments were significant over the control, however treatments $\left(\mathrm{T}_{4}\right.$ and $\left.\mathrm{T}_{7}\right)$ are statistically non significant to each other.

\section{In situ evaluation}

Germination percentage of chilli seedlings at 25 DAS

Results revealed that maximum germination percentage was recorded in $\mathrm{T}_{7}$ - Carbendazim [seed treatment] $(80.00 \%)$ followed by $\mathrm{T}_{4}-$ Lantana camara [soil treatment] $(76.00 \%), \mathrm{T}_{6}$ - Trichoderma harzianum + Pseudomonas fluorescens + Lantana camara [seed + soil treatment] (70.66 \%), $\mathrm{T}_{5}$ - Trichoderma harzianum + Pseudomonas fluorescens [seed treatment] $(68.00 \%), \mathrm{T}_{2}$ - Trichoderma harzianum [seed treatment] $(64.00 \%), \mathrm{T}_{3}$ Pseudomonas fluorescens [seed treatment] $(60.00 \%)$ when compared to the $\mathrm{T}_{0}$ - relative control (treated control) $(13.33 \%)$ and $\mathrm{T}_{1}$ absolute control (untreated control) (78.66\%).

Efficacy of treatments on the disease incidence of Pythium aphanidermatum in chilli at 15 days after sowing

Results revealed that minimum disease incidence was recorded in $\mathrm{T}_{7}$ - Carbendazim seed treatment $(20.00 \%)$ followed by $\mathrm{T}_{4}$ Lantana camara [soil treatment] $(24.00 \%), \mathrm{T}_{6}$ - Trichoderma harzianum + Pseudomonas fluorescens + Lantana camara [seed + soil treatment] (29.33\%), $\mathrm{T}_{5}$ - Trichoderma harzianum+ Pseudomonas fluorescens [seed treatment] (33.33\%), $\mathrm{T}_{2}$ - Trichoderma harzianum [seed treatment] $(36.00 \%), \mathrm{T}_{3}-$ Pseudomonas fluorescens [seed treatment] $(41.33 \%)$ when compared to the $\mathrm{T}_{0}$ - relative control (treated control) (86.66\%) and $\mathrm{T}_{1}$ absolute control (untreated control) (21.33\%). 
Table.1 Efficacy of selected treatments on the mycelial growth of Pythium aphanidermatum by dual culture technique and poisoned food technique

\begin{tabular}{|c|c|c|c|}
\hline Tr no. & Treatments & $\begin{array}{l}\text { Mycelial growth } \\
\text { of the pathogen } \\
(\mathbf{m m})\end{array}$ & $\begin{array}{l}\text { Per cent growth } \\
\text { inhibition }\end{array}$ \\
\hline $\mathbf{T}_{\mathbf{0}}$ & Relative control & 90 & 0 \\
\hline $\mathbf{T}_{2}$ & Trichoderma harzianum & 21 & 76.66 \\
\hline $\mathbf{T}_{\mathbf{3}}$ & Pseudomonas fluorescens & 25 & 72.22 \\
\hline $\mathbf{T}_{4}$ & Lantana camara & 0 & 100 \\
\hline $\mathbf{T}_{\mathbf{5}}$ & $\begin{array}{c}\text { Trichoderma harzianum } \\
+ \text { Pseudomonas } \\
\text { fluorescens }\end{array}$ & 17 & 81.11 \\
\hline $\mathbf{T}_{7}$ & Carbendazim ( check ) & 0 & 100 \\
\hline \multicolumn{2}{|r|}{ F -test } & $\mathrm{S}$ & $\mathrm{S}$ \\
\hline \multicolumn{2}{|r|}{ S.Ed. $( \pm)$} & 0.17 & - \\
\hline \multicolumn{2}{|r|}{ C.D. (at $0.05 \%$ ) } & 0.428 & - \\
\hline
\end{tabular}

Table. 2 Germination percentage of chilli seedlings at 25 DAS

\begin{tabular}{|c|c|c|}
\hline Tr no. & Treatments & $\begin{array}{c}\text { Germination } \\
\text { percentage }\end{array}$ \\
\hline $\mathbf{T}_{\mathbf{0}}$ & Relative control & 13.33 \\
\hline $\mathbf{T}_{\mathbf{1}}$ & Absolute control & 78.66 \\
\hline $\mathbf{T}_{\mathbf{2}}$ & Trichoderma harzianum & 64 \\
\hline $\mathbf{T}_{\mathbf{3}}$ & Pseudomonas fluorescens & 60 \\
\hline $\mathbf{T}_{\mathbf{4}}$ & Lantana camara & 76 \\
\hline $\mathbf{T}_{\mathbf{5}}$ & Trichoderma harzianum + & 68 \\
\hline $\mathbf{T}_{\mathbf{6}}$ & Pseudomonas fluorescens & 70.66 \\
& [Trichoderma harzianum & \\
\hline $\mathbf{T}_{\mathbf{7}}$ & Pseudomonas fluorescens] & 80 \\
\hline & Lantana camara & $\mathrm{S}$ \\
\hline & Carbendazim ( check ) & 1.03 \\
\hline & F -test & 2.205 \\
\hline
\end{tabular}


Table.3 Efficacy of treatments on the disease incidence of Pythium aphanidermatum in chilli at 15 days after sowing

\begin{tabular}{|c|c|c|}
\hline Tr no. & Treatments & $\begin{array}{c}\text { Disease } \\
\text { Incidence }\end{array}$ \\
\hline $\mathbf{T}_{\mathbf{0}}$ & Relative control & \\
\hline $\mathbf{T}_{\mathbf{1}}$ & Absolute control & 86.66 \\
\hline $\mathbf{T}_{\mathbf{2}}$ & Trichoderma harzianum & 21.33 \\
\hline $\mathbf{T}_{\mathbf{3}}$ & Pseudomonas fluorescens & 36.00 \\
\hline $\mathbf{T}_{\mathbf{4}}$ & Lantana camara & 41.33 \\
\hline $\mathbf{T}_{\mathbf{5}}$ & Trichoderma harzianum + Pseudomonas & 24.00 \\
\hline $\mathbf{T}_{\mathbf{6}}$ & fluorescens & 33.33 \\
\hline $\mathbf{T}_{\mathbf{7}}$ & Trichoderma harzianum + Pseudomonas & 29.33 \\
\hline & fluorescens] + Lantana camara & 20.33 \\
\hline & Carbendazim ( check ) & $\mathrm{S}$ \\
\hline & F -test & 1.02 \\
\hline
\end{tabular}

Table.4 Root length of chilli seedlings 45 days after sowing

\begin{tabular}{|c|c|c|}
\hline Tr no. & Treatments & Root length $(\mathbf{c m})$ \\
\hline $\mathbf{T}_{\mathbf{0}}$ & Relative control & 2.26 \\
\hline $\mathbf{T}_{\mathbf{1}}$ & Absolute control & 3.80 \\
\hline $\mathbf{T}_{\mathbf{2}}$ & Trichoderma harzianum & 3.56 \\
\hline $\mathbf{T}_{\mathbf{3}}$ & Pseudomonas fluorescens & 3.20 \\
\hline $\mathbf{T}_{\mathbf{4}}$ & Lantana camara & 3.11 \\
\hline $\mathbf{T}_{\mathbf{5}}$ & Trichoderma harzianum + Pseudomonas & 3.80 \\
\hline & fluorescens \\
\hline $\mathbf{T}_{\mathbf{6}}$ & [Trichoderma harzianum + Pseudomonas & 3.75 \\
\hline $\mathbf{T}_{\mathbf{7}}$ & fluorescens] + Lantana camara & 4.29 \\
\hline & Carbendazim ( check ) & $\mathrm{S}$ \\
\hline & F -test & 0.10 \\
\hline & S.Ed. $(\mathbf{+})$ & 0.18 \\
\hline
\end{tabular}


Table.5 Shoot length of chilli seedlings 45 days after sowing

\begin{tabular}{|c|c|c|}
\hline Tr no. & Treatments & Shoot length $\mathbf{( c m )}$ \\
\hline $\mathbf{T}_{\mathbf{0}}$ & Relative control & 2.10 \\
\hline $\mathbf{T}_{\mathbf{1}}$ & Absolute control & 4.31 \\
\hline $\mathbf{T}_{\mathbf{2}}$ & Trichoderma harzianum & 3.46 \\
\hline $\mathbf{T}_{\mathbf{3}}$ & Pseudomonas fluorescens & 3.26 \\
\hline $\mathbf{T}_{\mathbf{4}}$ & Lantana camara & 2.98 \\
\hline $\mathbf{T}_{\mathbf{5}}$ & Trichoderma harzianum + Pseudomonas & 4.10 \\
\hline $\mathbf{T}_{\mathbf{6}}$ & fluorescens & 3.90 \\
\hline & [Trichoderma harzianum + Pseudomonas \\
\hline $\mathbf{T}_{\mathbf{7}}$ & fluorescens] + Lantana camara \\
\hline & Carbendazim ( check ) & 4.52 \\
\hline & F -test & $\mathrm{S}$ \\
\hline & S.Ed. $\mathbf{\pm}$ ) & 1.02 \\
\hline
\end{tabular}

Root length and shoot length of chilli seedlings 45 days after sowing

Maximum root length was recorded in treatment in Trichoderma harzianum+ Pseudomonas fluorescens $(3.80 \mathrm{~cm})$ as compared to the treated control carbendazim $(4.29 \mathrm{~cm})$ and maximum shoot length was recorded in treatment Trichoderma harzianum + Pseudomonas fluorescens $(4.1 \mathrm{~cm})$ as to the treated control carbendazim $(4.52 \mathrm{~cm})$.

Based on the result it was observed that Lantana camara (soil application) proved to be most effective treatment under in-vitro and nursery conditions when compared to the carbendazim. The present study indicated that application of biocontrol agents singly and in combination with Lantana camara was found to be effective in controlling the chilli damping-off disease.

Hence, there is a need to search for an environmentally safe and economically viable strategy for the control of diseases and to reduce the dependence on the synthetic agrochemicals. In addition, bio- control agents are generally not effective if once the plants have been infected by Pythium and thus should not be considered curative control treatments. However, the present research findings are limited to one crop season under Allahabad agro-climatic condition as such more trials are required in future to validate the findings.

\section{References}

Gams W. and Bissett J. (1998). Morphology and identification of Trichoderma. In Trichoderma and Gliocladium, (Eds) by C. P. Kubicek\& G. E. Harman. London; Bristol, PA: Taylor \& Francis. 3-31.

Gholve, V. M., Tatikundalwar, R., Suryawanshi, A. P. and Dey, U. (2014). Effect of fungicides, plant extracts / botanicals and bio - agents against damping- off in brinjal. African Journal of Microbiology Research, 8(30):2835-2848.

Ghutukade, K. S., Lal, A. and Raut, S. A. (2013). Effect of seed treatment with fungicides and bio-agents on dampingoff of chilli caused by Pythium aphanidermatum. Trends in 
Biosciences, 6(4):490-493.

Jeyaseelan, E. C., Tharmila, S. and Niranjan, K. (2012). Antagonistic activity of Trichoderma spp. and Bacillus spp. against Pythium aphanidermatum isolated from tomato damping - off. Archives of Applied Science Research, 4(4):1623-1627.

Khan, M. R., Khan, S. M. and Mohiddin, F. A. (2004). Biological control of Fusarium wilt of chickpea through seed treatment with the commercial formulation of Trichoderma harzianum and / or Pseudomonas fluorescens. Phytopathologia Mediterranea, 43:20-25.

Kloepper J. W, Lifshitz, R. and Zablotowicz, R. M. (1989). Free-living bacterial inocula for enhancing crop productity. Trends Biotechnolpgy, 7:39-43.

Muthukumar, A., Eswaran, A., Nakkeeran, S. and Sangeetha, G. (2010a). Efficacy of plant extracts and biocontrol agents against Pythium aphanidermatum inciting chilli damping-off. Crop Protection, 29:1483-1488.

Nikam, P. S., Jagtap, G. P. and Sontakke, P. L. (2007). Management of chickpea wilt caused by Fusarium oxysporium f. sp. ciceri. African Journal of Agricultural Research,2(20):692-697

Patel, J. K., Joshi, K. R., Prajapati, H. N. and Jage, N. P. (2014). Bait Techniques for Isolation of Pythium aphanidermatum causing damping - off of chilli from soil and efficacy of bio - agents In vitro. Trends in Biosciences, 7(6):474476.

Raghunandan, B. L., Asha, N. N. and Shivaprakash, M. K. (2013). Role of biological control agents in suppression of damping - off disease in chilli. Bioinfolet, 10(1):258-262.

Parija, C. and Parabhakar, P. K. (1995). Journal of Clinical Microbiology, 33(4): 1019-1021.

Plaats-Niterink, and Van der, A. J. (1981). Monograph of the genus Pythium. Studies in Mycology, 21(1-2)44.

Sandheep, R, A. and Jisha, M. S. (2013). Screening of Trichoderma spp. and Pseudomonas spp. for their bio-control potential against phytopathogens of vanilla. International Journal of Agriculture, Environment \& Biotechnology, 6:799-806.

Tuite, J. (1969b).Plant pathological method, fungi and bacteria. Burgess: Minnesota pp. 100-101.

Vincent, J. M. (1927). Distortion of fungal hypha in presence of certain inhibitor nature, 159:850.

Zagade, S. N., Deshpande, G. D., Gawade, D. B., Atnoorkar, A. A. and Pawar, S. V. (2012). Bio - control agents and fungicides for management of damping off in chilli. World Journal of Agricultural Sciences, 8 (6):590-597.

\section{How to cite this article:}

Gandham Grace Susanthi and Sunil Zacharia. 2021. Efficacy of Bio - Agents and Lantana camara against Damping - Off (Pythium aphanidermatum) of Chilli (Capsicum annuum L.). Int.J.Curr.Microbiol.App.Sci. 10(06): 637-645. doi: https://doi.org/10.20546/ijcmas.2021.1006.070 